\title{
人エタイドプールの開発 \\ DEVELOPMENT OF ARTIFICIAL TIDE POOL UNITS
}

\author{
綿貫 啓 1 廣瀬紀 ${ }^{2} \cdot$ 長谷川 実 1 高橋邦正 ${ }^{2} \cdot$ 古澤 晃 ${ }^{2}$ \\ Akira WATANUKI, Norikazu HIROSE, Minoru HASEGAWA, Kunimasa TAKAHASHI \\ and Akira HURUSAWA \\ ${ }^{1}$ 工修 株式会社テトラ（テ160-8350 東京都新宿区西新宿6-3-1） \\ 2 株式会社テトラ（テ160-8350 東京都新宿区西新宿6-3-1）
}

\begin{abstract}
The natural coast continues to undergo changes, but structures such as seawalls now serve only one purpose, i.e. protection. In recent years, as ecofriendly structures are desirable, artificial rocky beaches are now projected as places of recreation where people can learn about shorelife. Unfortunately, in many cases, due to the lack of storing water in rocky beaches at low tide, the biota therein shows little diversity. Observation of a natural beach was conducted at Kominato in Chiba. Tide pools provide very valuable, habitats for seaweed and sea creature. They have the important function of not only storing water, but also providing micro-topographes in the pool such as cracks, crevices and pits. Accordingly, new artificial tide pool units have been developed, which fill up with seawater during the ebb tide to ensure suitable micro-topography for shorelife. An example of the design method of such a system is provided.
\end{abstract}

Keywords: Artificial rocky beach, Marine organisms, Tide pools

\section{1.はじめに}

沿岸域の整備に際して、防災機能だけでなく、親 水性、自然環境との調和、とりわけ生物との共生へ の配虑に対する要請が強まっている。これまで汀線 際に設置された構造物は、天然の海岸線を減少させ、 本来の陸と海との間に連続的に変化する生態系を分 断するものも少なくはなかった。このような要請や 反省から、砂浜では養浜等の人工海浜の計画時に、 二枚貝の増殖やウミガメの産卵等に配虑がなされる ようになってきた。

岩礁海岸については、内湾域や比較的静穏な海域 において、レクリェーションの場、親水空間、生物 の生息場として、人工磯の施工が増えてきている。 しかしながら、これまでの人工磯は、景観機能を重 視した施設が多く、潮間帯に生息する生物を対象と はしているものの、多様な生息空間の形成に対する 配虑は必ずしも十分とは言えない。

そこで、著者らは、天然岩礁海岸の生物分布調查 を実施し、岩礁域において生物相が多様な「潮だま り(タイドプール)」に着目した。タイドプールに ついては、人工磯と天然磯との生物分布の比較に関 する先駆的な調査でも、その重要性が指摘されてい $ろ^{11}{ }^{2)}$ 。ここでは、天然岩礁での生物分布の特徴を 整理し、人工磯の生物相を豊かにする手段として、
天然の岩礁を模做したプレハブ式の人エタイドプー ルを考案したので、その経過と利用方法の検討結果 を示す。

\section{2. 人工磯の事例調査}

人工磯は、全国的に見るとその事例はまだ少ない。 著者らが現地踏査した人工磯の施工事例を表-1に示 す。

外海に面した人工磯はなく、内湾もしくは防波堤 等の背後の比較的静稳な場所に立地している。背後 に海浜公園や海岸の散策道が隣接する場合が多く、 海釣りや磯遊びなどのレクリェーション機能が期待 され、親水性や景観の演出に重点が置かれている。

材料は、大井埠頭のように内湾であれば、砂喽も 使用されるが、波浪がやや厳しい場所では、安定性 の確保から $500 \mathrm{~kg}$ 内外から数 $\mathrm{t}$ の捨石が使用されて いる。同サイズの捨石を敷き詰める場合、捨石間に 複雑な空隙ができるものの、類似した空隙になり、 生物の生息空間としては多様性に欠けると推察され た。

汀線の平面形状は、航路に面した埋め立て護岸で は沖に張り出せず、捨石の複雑さは有するが、直線 的な海岸地形となっている。構造物上の付着生物の 分布を制限する物理条件は、構造形式と波浪の大き 
表-1 主な人工磯の施工事例

\begin{tabular}{|c|c|}
\hline 地 区 名 & 徵 \\
\hline $\begin{array}{l}\text { 相馬港 } \\
\text { 原釜地区 }\end{array}$ & $\begin{array}{l}500 \mathrm{~kg} \text { 内外の捨石を敷き詰め、親水性を高めた磯遊びのための施設。岬や入り江風の海 } \\
\text { 岸地形を表現。 }\end{array}$ \\
\hline $\begin{array}{l}\text { 東京港 } \\
\text { 大井埠頭中央海浜公園 }\end{array}$ & $\begin{array}{l}\text { 大小さまざまな捨石を並べている。砂碟が混合し、地形の多様性があり、一部干潟化し } \\
\text { ている。内湾の生物が豊か。 }\end{array}$ \\
\hline $\begin{array}{l}\text { 東京港 } \\
\text { 若洲海浜公園 }\end{array}$ & $\begin{array}{l}500 \mathrm{~kg} \sim 5 \text { t程度の捨石を並べ、海釣りや磯遊びをめざした施設。護岸に沿った直線的な } \\
\text { 海岸。 }\end{array}$ \\
\hline $\begin{array}{l}\text { 横浜港 } \\
\text { 金沢地区海の公園八景島 }\end{array}$ & $\begin{array}{l}500 \mathrm{~kg} \sim 5 \text { t程度の捨石を並べ、遊歩道や階段護岸に隣接して親水性を高めている。海岸 } \\
\text { 線は起伏を持たせ、小規模なコンクリート製タイドプールも設置。 }\end{array}$ \\
\hline $\begin{array}{l}\text { 三河港 } \\
\text { 三河臨海緑地 }\end{array}$ & $\begin{array}{l}500 \mathrm{~kg} \sim 2 \text { t程度の捨石を並べ、複雑な海岸地形を表現。背後の公園と一体となった造園 } \\
\text { 的なデザイン。 }\end{array}$ \\
\hline $\begin{array}{l}\text { 敦賀港 } \\
\text { 鞠山北地区 }\end{array}$ & $\begin{array}{l}\text { 大水深の護岸の上部に } 500 \mathrm{~kg} \text { 内外の捨石を張った構造。階段護岸やデッキを設け、親水 } \\
\text { 性を高めている。. }\end{array}$ \\
\hline $\begin{array}{l}\text { 大阪港 } \\
\text { 舞洲地区 }\end{array}$ & $\begin{array}{l}50 \mathrm{~kg} \sim 1 \mathrm{t} \text { 程度の捨石を並べ、10t程度の巨石を部分的に配置。遊歩道や階段護岸に隣接 } \\
\text { して親水性を高めている。護岸に沿った直線的な海岸。 }\end{array}$ \\
\hline $\begin{array}{l}\text { 大阪府 } \\
\text { 淡輪・箱作海岸 }\end{array}$ & $\begin{array}{l}\text { 小磷の䂺浜や } 500 \mathrm{~kg} \text { から巨石までの磯浜を配置し、複雑な海岸地形を表現。ケーソンタ } \\
\text { イプの大小のタイドプールを設け、生態系保全、自然観察の場をめざした施設。 }\end{array}$ \\
\hline
\end{tabular}

さの影響が強く ${ }^{3)}$ 、直線的な海岸では波当たりがほ ぼ均等であるので、付着生物の量や種に変化がなく なると推測される。事例の中でも、フナムシ、イワ フジツボ、カニ類、ラン藻網、珪藻網のみの比較的 単調な生物相が続く人工磯も見られた。一方、海岸 地形が複雑な事例では、波当たりに差が生じ、それ に応じて生物相も変化しているものと考えられる。

捨石は砕石がほとんどで、石の表面は凸部が多く、 窪みや亀裂が少ない。したがって、干潮時の貯水機 能がほとんどなく、干出した部分はラン藻網、珪藻 網あるいはアオノリ属の限られた藻類と、フジツボ 類や力キなどの耐乾性の付着生物が多く観察される 程度で、他は巻貝類やカ二類などの移動性の動物で あった。一方、人工磯に貯水性のあるタイドプール が存在すると、タイドプール内には海藻類が多く分 布し、逃げ遅れた小魚や乾燥に弱い生物も見られ、 生物相を多様にしている。

\section{3.天然磯の生物調査}

人工磯踏査の結果、生物相を豊かにするには、干 潮時でも貯水され、干出しないタイドプールの存在 が大きいことが想定された。そこで、人工磯の計画 に際し、タイドプールを含む天然磯の生物相の実体 を把握する現地調査を行った。

\section{(1) 調查方法}

本調査では、千葉県安房郡天津小湊町にある千葉 大学理学部付属海洋生態系研究センター小湊実験場 付近に分布する天然岩礁を対象とした（図-1）。安 房層群天津層に位置し、青灰色から緑色の泥岩を主
体とした地層である ${ }^{4)}$ 。

岩盤には大小様々なタイドプールが存在するが、 これらを含めるように潮間帯上部から下部まで、ラ インを張り、幅50 c mのベルトトランセクトによる 生物の被度調査を行った。地形の測量はレベルを用 いた。波の入射方向は南〜東である。ラインAは波 当たりの強い岩礁で、ライン $\mathrm{B}$ は波当たりが比較的 穏やかな岩礁である。

次に、ラインA近傍の 9 個のタイドプール内の生 物の被度調查と各プールの水面の平均海面からの高 さを測定した。これらの調査は、平成 9 年 8 月 6 日 と7日の干潮時に実施した。

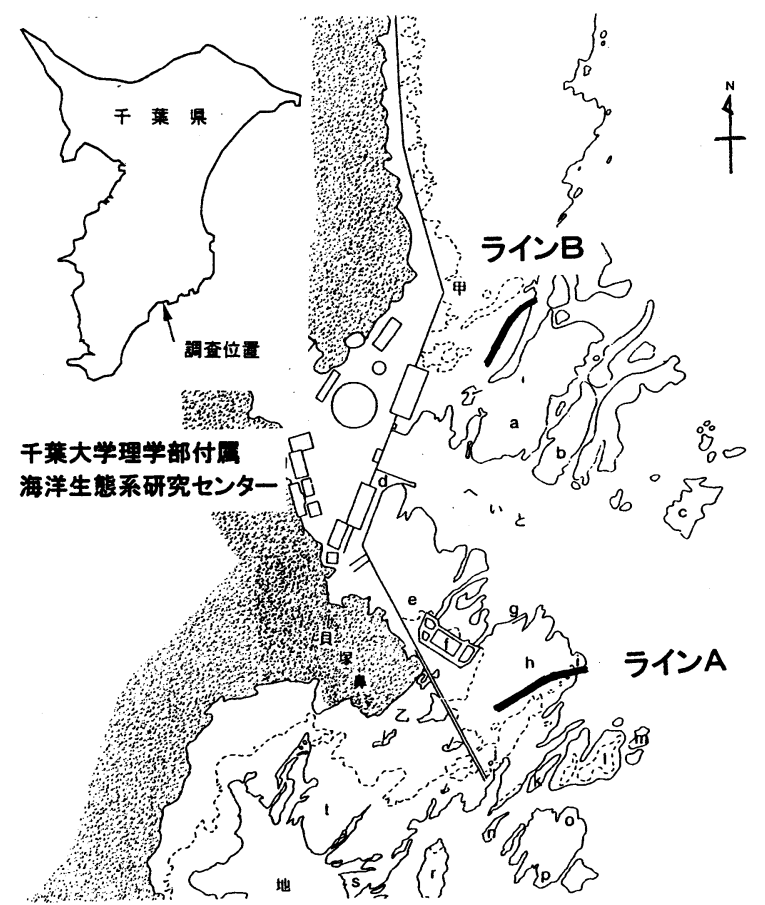

図-1 調查位置（天津小湊町）と調查ラインの位置 


\section{(2) 岩礁上の生物分布の調查結果}

図-2,3に各ラインに沿った地形と幅 $50 \mathrm{~cm}$ 分布 する生物の被度（\%）の分布を示す。

ラインAには 6 個のタイドプールが含まれている。 各タイドプールの外縁の干出する部分は、MW L 以 上ではラン藻網、珠藻網が優占し、動物ではカラマ ツガイ、シロカラマツガイ、イワフジツボ等の耐乾 性の種が分布しているが、種類数は少ない。

タイドプール内には貯水性があるため海藻類が分 布し、地盤の高いタイドプール(1)では珪藻網、その 下方のタイドプール(2)ではアオノリ属、さらに、平 均水面の高さに近いタイドプール(3)では立体的な褐 藻のウミトラノオ、紅藻のピリヒバ、動物では濾食 性のカイメンが出現している。 MW L 以下のタイド プール(4)〜(6)になると、海藻類の種類がさらに増え 立体的な海藻類により複雑な空間が形成され、ヨ口 イイソギンチャクや藻食性のヒザラガイが出現し、

動物も多くなる。

波当たりの小さいラインBでも、干出する部分に ラン藻網・珪藻網、およびこれらの微小藻類を飰と するウノアシガイが分布している。タイドプールに は海藻類が優占するが、波当たりが小さいため、波 当たりが大きな海岸に多く分布するヒジキやウミト ラノオ等の大型の海藻の被度は小さく、無節サンゴ モやピリヒバ、ソゾ属（(5)〜7) が優占している。

以上のように、天然磯で干潮時に干出する部分は ラン藻等の微細藻類とカラマツガイなどの耐乾性の 動物が分布するのみであるが、タイドプールが存在 すると、その貯水性から、海藻類が繁茂し、動物も 多く、多様な生物相を形成することがわかる。

また、タイドプールの位置する高さや波当たりの 強さによって、分布する生物の種組成が変わるので、 人工磯の計画に際し、タイドプールの波当たりの異 なる場所や設置高さにバラェティーを持たせること で、個々に種組成の異なる生物相を優占させ、生物 相の多様な人工磯が形成させ得る可能性があると考 えられる。

\section{(3)タイドプールごとの生物調査結果}

表-2にラインA付近における大小 9 個のタイドプ 一ル内に分布する生物の被度をタイドプールの水面 高さが低い順に示した。また、図-4にタイドプール の水面の平均海面上の高さと海藻類の累積被度およ び海藻、動物の種数の関係を示した。ここでは、被 度は各タイドプールの底面積における各生物の占め る割合を示す。また、累積被度は小型から大型海藻 まですべての海藻ごとの被度を合計したものなので、 $100 \%$ 以上になり得る。

表-2によると、平均海面から $19 \mathrm{~cm}$ 上に水面のある タイドプール(1)には砂が堆積しており、海藻類の被
度は低い。また、30 c m上のタイドプール(2)では䃯 が堆積しているが、礫の安定性がやや高いため、海 藻類が付着している。砂䃯が堆積していない場合に は、図-2,3に見られたように、これらの高さのタイ ドプールでは褐藻のウミトラノオが着生するはずで ある。

タイドプール内に石があると生息する動物の多様 性が上がることが指摘されている2゙。確かに、動物 や魚の隠れ場として安定な石は有望と考えられるが、 このタイドプールに見られるように、不安定な石あ るいは砂利などが堆積するタイドプールでは、波に よる底質の移動で生物、特に移動できない海藻類は 生育しにくくなるので注意が必要である。
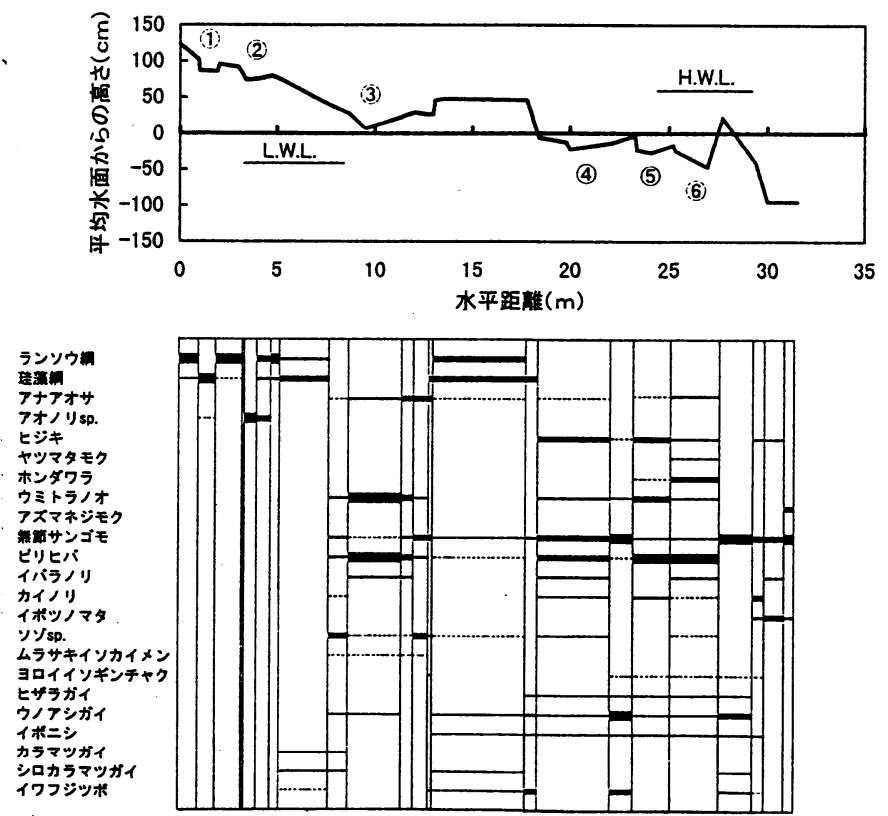

図-2 ラインAに沿った被度 $(\%)$ 分布
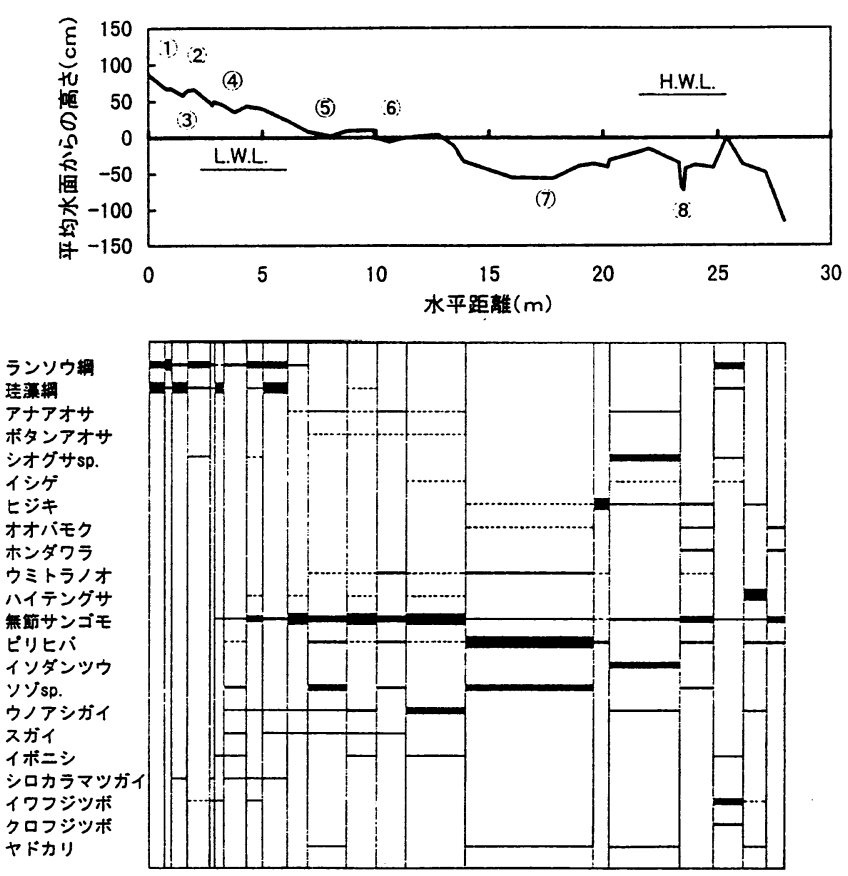

図-3 ラインBに沿った被度 $(\%)$ 分布 
平均海面上 $35 \mathrm{~cm}$ のタイドプール(3), (4)（深さ30〜 $60 \mathrm{~cm})$ では褐藻類や紅藻類が分布し、貝類の種類数 も多い。図-4においてもその傾向が明らかである。 また、魚類のアゴ八ゼもプール内に取り残されてい た。平均海面から $44 \mathrm{~cm}$ 以上の高さのタイドプールで は緑藻が優占するが、日射や降雨等で水温や塩分が 激しく変わる不安定な環境であり動物は少ない。こ の海岸のHW L は+ $60 \mathrm{~cm}$ であるが、それより $20 \mathrm{~cm}$ 上高いタイドプールでも緑藻が分布している。これ は、波による打ち込みによるものと考えられる。

図-2，3，4や表-2の結果を総合すると、MW L 前 後およびそれ以深では褐藻類が分布し、 $+35 \mathrm{~cm}$ 前後 では海藻類に加え、動物の種数も増える。さらに、 +40〜 HW L 前後では緑藻が主体のタイドプールに なる。したがって、人工磯の計画に際し、タイドプ 一ルの高さを選定すれば、個々に異なる生物相の夕 イドプールとすることができると考えられる。

この海岸では、MW L 付近、 $+30 \mathrm{~cm}$ 付近、HW L 付近のように、高さに $20 \sim 30 \mathrm{~cm}$ 差を持たせたタイ ドプールを設置すると、生物相の異なるタイドプー ルが形成できると考えられる。

\section{(4) 岩礁の微地形と付着生物の関係}

タイドプールの外縁の干潮時に露出する部分には、 前述したように、カラマツガイなどの耐乾性の動物 が分布するが、天然岩盤には亀裂や窪みなどの微地 形が存在し、ここは水をたたえるためになかなか乾 燥しない。

今回の観察では、幅 $2 \sim 5 \mathrm{~cm}$ 程度の亀裂には、カ メノテ、イシダタミガイが多く、亀裂の奥にはイソ ガニやイソギンチャク類が潜んでいた。また、幅 5 〜 $6 \mathrm{~cm}$ 程度で深さ $1 \sim 2 \mathrm{~cm}$ 程度の䆶みには、ヒザラ ガイやスガイ、イシダタミガイ、ウノアシガイなど のやや耐乾性のある貝類が競い合って付着していた。 図-5にラインAのMW L 以下のタイドプール (4)〜 (6) に分布しているヒザラガイの生息する窪みの短径と 長径の関係を示す。長径の約 7 割が短径であり、こ の大きさはおおむねヒザラガイ 1 個の大きさに匹敵 しており、自分の体の大きさに合った窪みを選択し ていると考えられる。

このように、干潮時に干出する部分でも微地形を 再現することによって、さらに生物相を豊かにする ことが可能である。定性的ではあるが、これらの生 物は、岩盤表面に入っている水平な亀裂より、鉛直 上下方向の亀裂に多く生息している傾向にあった。 これは、これらの生物がいずれも乾湿の状況に応じ て最も生息しやすい高さを選択するので、鉛直方向 の亀裂の方が選択の自由度が高いためと考えられる。 なお、亀裂については、タイドプール内からの生 物の移動の連続性を考虑して、内部にも亀裂状の溝
表-2 各タイドプール内の生物の被度
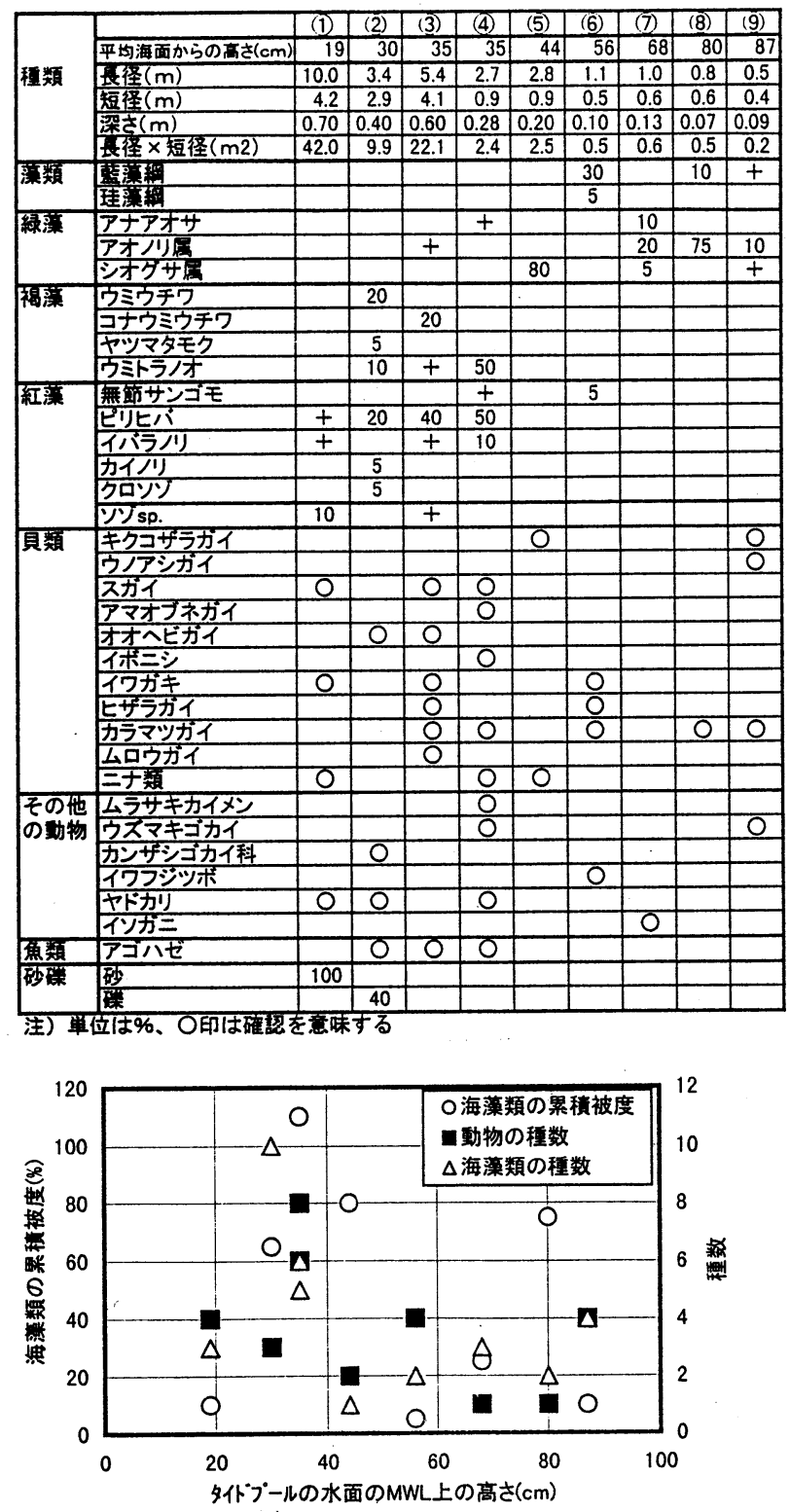

図-4 タイドプールの高さと生物分布

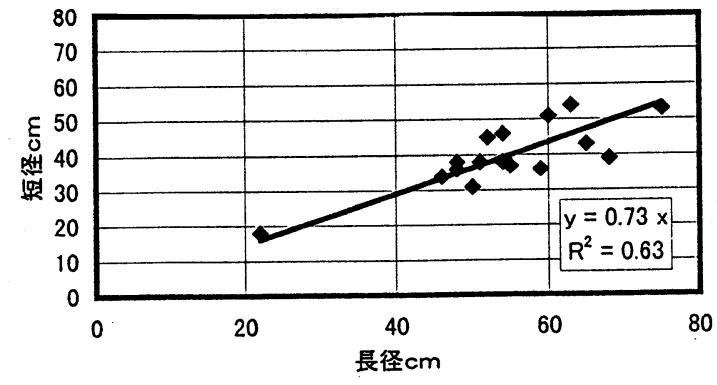

図-5 ヒザラガイが生息する岩礁の窪みの長径と短 径の関係

を配することが望ましく、匍匐性の貝類、ヤドカリ 類、イソガニ類などの移動性の動物の害敵からの逃 げ場を提供できるものと考えられる。また、亀裂は 乾燥しにくく、保水性があるので、干出しても珠藻 やラン藻のみでなく、緑藻類の着生が期待できる。 


\section{4.人エタイドプールの開発}

(1)人工磯の生物相を豊かにするための条件

天然岩礁の調查結果から、人工磯の生物相を豊か にするための条件を以下にまとめる。

(1)干潮時に、貯水機能を有する染さ $30 \sim 60 \mathrm{~cm}$ のタイ ドプールを確保する。

(2)タイドプールの設置高さを、潮間帯の中で $2 \sim 3$ 通りに選定する。

(3)波当たりの強さの異なる位置にタイドプールを設 置して、物理的外力の差による生物分布の多様性を 出す。

(4)タイドプールの干出部分は微地形を再現して、窪 みや亀裂を設ける。窪みは $5 \sim 6 \mathrm{~cm}$ 、深さ $1 \sim 2 \mathrm{~cm}$ とし、亀裂は幅 $2 \sim 5 \mathrm{~cm}$ で鉛直方向が望ましい。

(5)タイドプール内の動物を多くするには、波で動摇 しない安定な石を設置する。

従来の人工磯は経済的な理由から捨石を使用して いる。人工磯踏查でも述べたが、捨石では凸面が多 く保水・貯水機能に欠け、また、個々の砕石を並べ ても貯水機能のあるタイドプールはできない。した がって、貯水性を確保するコンクリート構造物によ るタイドプールと、経済的な捨石の組み合わせが望 ましいものと考えられる。

\section{(2)タイドプールユニットの考案}

以上のように、人工磯の生物相を豊かにするため に、コンクリート製のタイドプールユニット（図6）を考案した。

ユニット化した理由は以下のとおりである。

(1)潮間帯の潮待ち作業なので、コンクリートの場所 打ちではなく、施工が短期間で容易なプレハブ化が 望ましい。

(2)潮間帯では大きな重機が利用しにくいので、重量 が軽い小型のブロックがよい。

(3)タイドプールの全体形状が一様であると、景観上 望ましくない。種々の形状のタイドプールが形成で きることが望ましい。

この条件を満足させるため、タイドプールを 5 種 類のモジュールで表現することとし、各々をユニッ ト化した。特徴は次のとおりである。

(1) 5 種類のユニットを並べることで、最大深さ $50 \mathrm{c}$ $\mathrm{m}$ で任意の形状のタイドプールが形成できる（図7) 。

(2)ユニットは 1 辺が $2 \mathrm{~m}$ で、重量は約 $3 \sim 5 \mathrm{t}$ で軽 量である。なお、設計条件に応じて、ユニットの基 盤を厚くすることで重量を増加させ、波浪等の外力 に対する安定性を増すことが可能である。

(3)ユニット相互を連結し、目地処理を施すことで貯 水機能を持たせている。
(4)鉄筋コンクリート製であるが、表面は天然岩盤か ら型をとり、岩表面の微地形（亀裂や涳み）を忠実 に再現する擬岩工法を用いている。

(5)表面は顔料を混練りしたCF R C (炭素瀻維補強 コンクリート）で耐久性がよく、周辺の岩の色に一 致させることができるので、景観を阻害しない。

(6)捨石マウンド上に設置するので、マウンドの高さ を調節することで、設置高さを自由に変化させるこ とができる（図-8）。

図-9にユニット9 個（重量 3〜 $5 \mathrm{t} /$ 個）を用い た試作事例を示す。目地を止水処理してあり、貯水 機能がある。タイドプールの表面は、亀裂や窪みの ある天然の岩礁表面の微地形を模写した。また、亀 裂は幅 $2 \sim 5 \mathrm{~cm}$ とし、できるだけ鉛直（上下）方向 に配置し、干出する外縁部分の上面には、ヒザラガ イやイシダタミガイが着生しやすいように、幅 5 〜 $6 \mathrm{~cm}$ で梁さ 1 〜 $2 \mathrm{~cm}$ の窪みを配置した。
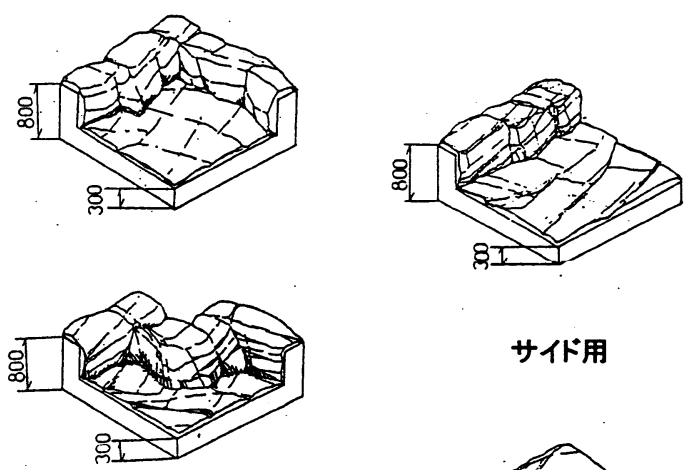

サイド用
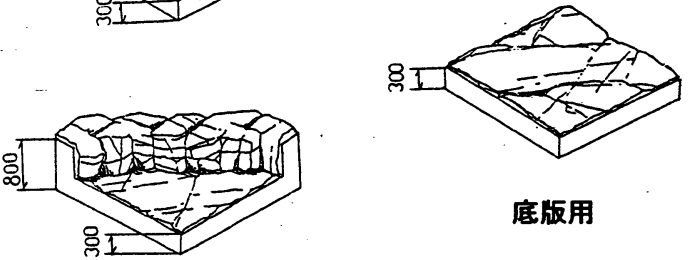

底版用

$$
\text { コーナー用 }
$$

図-6 5 種類のタイドプールユニット
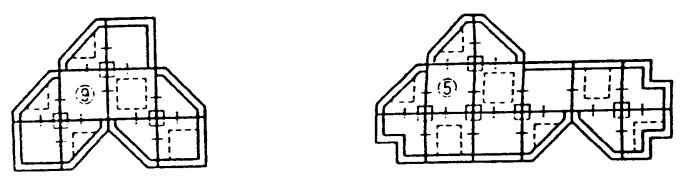

ユニットの平面眍置例
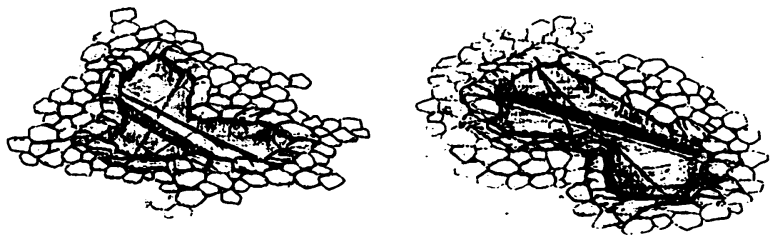

配置例の鳥駇図

図-7 ユニットの組み合わせ例 

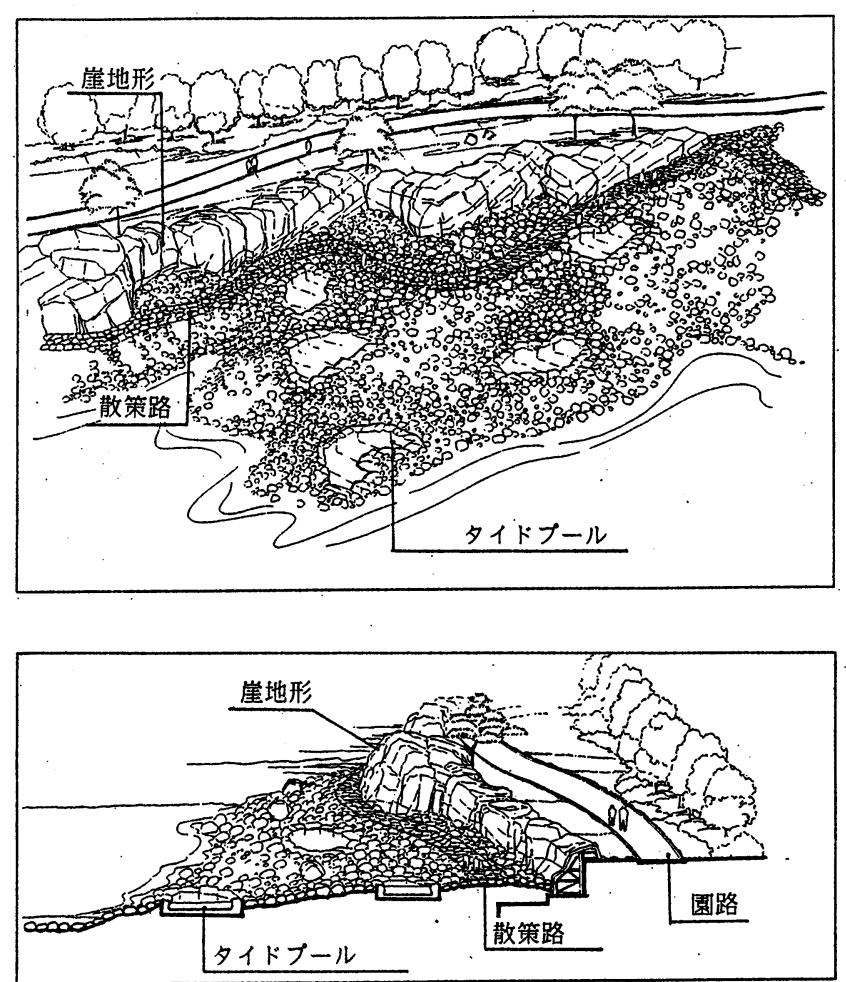

図-8 計画事例

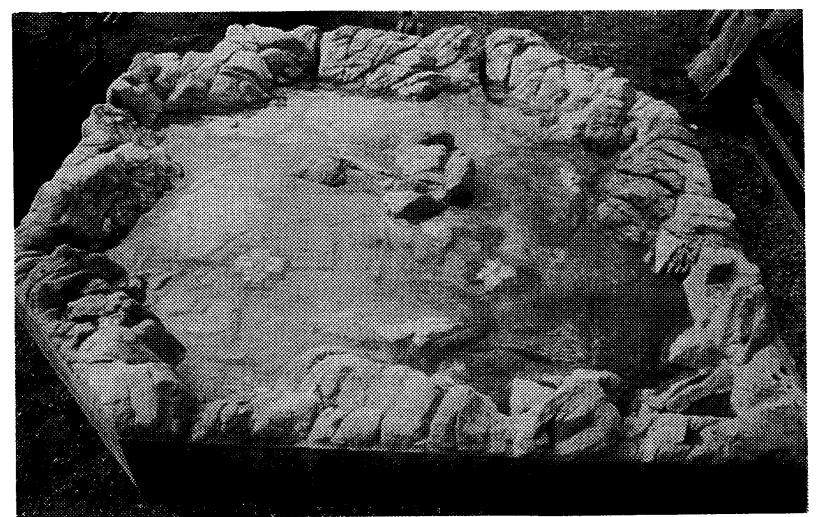

図-9 試作事例（ユニット9個使用）

\section{6. おわりに}

近年、要望が増えつつある人工磯に対して、生物 相を豊かにし、親水機能や景観機能も良好にする手 段としてタイドプールに着目した。タイドプールを 含む天然岩礁の調查を実施し、

・タイドプールの貯水機能により、プール内は海藻 が優占し、生物相が豊かになること

・タイドプールの位置する平均海面からの高さや波 当たりによってプール内の生物相が変化すること
・タイドプール内の不安定な砂利や砂の存在は、生 物相を貧弱にすること

-干出する岩礁表面では亀裂や窪みの湿潤な微地形 に多くの生物が蝟集すること

等がわかった。

そこで、これらの要件を達成する一つの方法とし て、任意の形状で高さを自由に設定することが可能 なユニットタイプのタイドプールを考案した。陸上 での試作を終え、現在、実海域での施工を実施中で ある。

実施工にあたっては、事前調査として周辺の岩礁 の潮間帯における生物調査を実施し、その結果から、 生物相を豊かにするためのタイドプールの設置高さ を求めた。この効果については、施工後の生物調査 を計画しているので、別の機会に報告することにし たい。

なお、ここでは、タイドプールを中心として報告 したが、磯生物にはフナムシやイワガニなど、浜に 打ち上げた有機物を捕食する生物も分布する。この ような種に対しては、海中の生物相が豊かである必 要があり、海中から潮間帯あるいは陸上まで含めて 一体とした生態系への配慮が必要と考える。

謝辞 : 天然磯の生物調査にあたっては、千葉大学海 洋生態系研究センター小湊実験所の平野義明博士に 多大な便宜を頂いた。また、生物調査については、 株式会社海藻研究所の新井章吾氏に全面的に協力し て頂いた。ここに記して謝意を表する。

\section{参考文献}

1）井上雅夫, 島田広昭, 鉄川精, 中村克彦: 生物 との共生をめざした人工磯の生態工学的研究, 海 岸工学論文集, 42, pp. 1191-1195， 1995.

2）井上雅夫, 島田広昭, 鉄川精, 柄谷友香: 生物 との共生をめざしたタイドプールの造成に関する 現地調査, 海洋開発論文集, 12, pp. 479-484. , 1 996.

3）小笹博昭, 室善一郎, 中瀬浩太, 綿貫啓, 山本 秀一: 生物にやさしい港湾構造物の研究一波高条 件および港湾構造物形式より見た付着生物群集一, 海岸工学論文集, 41, pp. 1016-1020， 1994.

4）藤沼伸幸, 小竹信宏 : 天津小湊町に分布する中 新統天津層から産出する炭酸塩ノジュール, 千葉 大学理学部海洋生態研究センター年報, 15, pp. 1 4-22. , 1995.

（1999.4.19受付） 